\title{
O MICROEMPREENDEDOR INDIVIDUAL A LUZ DA TEORIA POLIÉDRICA DE ALBERTO ASQUINI
}

\section{THE INDIVIDUAL MICROENTERPRISE LIGHT OF POLYHEDRAL THEORY OF THE ALBERTO ASQUINI}

\author{
${ }^{1}$ Saulo Bichara Mendonça \\ ${ }^{2}$ Pablo Gonçalves e Arruda
}

\section{RESUMO}

A Lei Complementar $n^{\circ} 123 / 0$ e suas alterações institui o microempreendedor individual, com fundamento na livre iniciativa. As características legais que lhes são atribuídas parecem alijadas do perfil corporativo da empresa estabelecido por Alberto Asquini, com similitude com a Teoria da Firma de Ronald Coase, o que talvez impeça que se verifique o microempreendedor individual como o empresário conceituado à partir da Teoria da Empresa. Desta forma, o presente estudo tem como objeto a revisão do conceito de microempreendedor individual a fim de verificar se este agente econômico pode de fato ser reconhecido inteiramente como um empresário.

Palavras-chave: Empresário, Microempreendedor individual, Teoria da empresa

\begin{abstract}
Supplementary Law No. 123/0, as amended establishing the individual microenterprise, based on free enterprise. The legal characteristics assigned to them seem pushed out of the company's corporate profile established by Alberto Asquini with similarity to the theory of Ronald Coase Firm, which pervhaps makes it impossible to check the individual microenterprise as the renowned entrepreneur starting Company Theory. Thus, the present study has as its object the individual microenterprise concept review to check if this economic agent may indeed be entirely recognized as an entrepreneur.
\end{abstract}

Keywords: Businessman, Individual microenterprise, Company theory

\footnotetext{
${ }^{1}$ Pós-Doutor pela Universidade do Estado do Rio de Janeiro - UERJ, Rio de Janeiro, RJ. Professor da Universidade Federal Fluminense - UFF, Ri ode Janeiro, RJ. (Brasil). .E-mail: saulobmendonca@ live.com.

${ }^{2}$ Especialista em Direito do Consumidor pela Pontifícia Universidade Católica do Rio de Janeiro - PUC-Rio, Rio de Janeiro, RJ. Profesor na Escola da Magistratura do Estado do Rio de Janeiro - EMERJ, Rio de Janeiro, RJ. (Brasil). E-mail: pabloarruda@smga.com.br.
} 


\section{INTRODUÇÃO}

O microempreendedor individual - MEI, conceituado pela Lei Complementar $n^{\circ}$ 123/06 ${ }^{1}$, nos termos trazidos pela Lei Complementar 128/08, é identificado como sendo uma pessoa física que trabalha por conta própria e que se legaliza como uma das espécies de micro empresário, estando autorizado por lei a faturar o máximo de sessenta mil Reais por ano, quantia que deve ser comprovada por sua declaração fiscal e se for superada seu enquadramento como tal resta prejudicado, sendo possível inclusive a cominação de sanção por irregularidade fiscal.

Cabe observar que, consoante determina o artigo 68 da Lei Complementar no 123/06, o pequeno empresário é outra espécie do gênero microempresário, não se confundindo com o microempreendedor individual em caracterização e efeitos.

Ao microempreendedor individual não é lícito à participação em outra atividade empresária, seja como sócio ou titular, inobstante qual seja o segmento e o tipo jurídico adotado. Ele pode ter um até um colaborador da empresa, contratado por remuneração não superior a um salário mínimo ou o correspondente ao piso da categoria funcional na qual se enquadre.

Desta forma, a análise criteriosa do chamado microempreendedor individual se faz imperiosa a fim de verificar se este agente econômico de fato pode ser reconhecido como um empresário de direito ou se sua regulamentação pode dar azo ao reconhecimento de um agente econômico diverso ou a variável diversa a ser reconhecida.

Destarte, a partir do objeto delineado para este estudo, tem-se por objetivo geral a pretensão de verificar se o produto da atividade legislativa tem guardado compasso com a propositura da Teoria da Empresa sob a qual se pretendeu filiar, fundamentando a norma conceitual a partir de 2002, quando se propôs a unificação dos ramos do direito civil e empresarial $^{2}$, a despeito de não haver submissão da norma especial perante a geral. Espera-se

\footnotetext{
${ }^{1}$ A título de observação, se faz importante observar que, apesar de ter sido a LC 128/08 a Lei alteradora criadora do microempreendedor individual, a Lei Complementar $n^{\circ} 123 / 06$ sofreu alterações também pela Lei Complementar $n^{\circ} 147 / 14$, além de ter tido quatro textos alterados pela Lei $n^{\circ} 12.792 / 13$, a despeito da estranheza que causa uma Lei Ordinária dar redação à texto de Lei Complementar.

${ }^{2}$ São comuns e de conhecimento geral os estudos que fazem menção à Teoria da Empresa como fundamento para a legislação empresarial pátria, reestruturada a partir do Código Civil de 2002. Contudo, ressalta-se que a referida teoria contribuiu na Itália para a unificação do direito privado. No Brasil, esta unificação é relativa, primeiro porque ainda não se propôs a revisão das leis trabalhistas, inobstante a qualidade e quantidade de demandas que se possa inventariar em justificativa para tanto, em segundo porque, a interpretação dos direitos ditos privados tem se dado à luz da Constituição Federal de 1988, no processo conhecido por constitucionalização dos direitos privados. Porem, o aprofundamento nesta temática exige uma reprogramação metodológica em outro estudo, de forma que, esta nota tem pretensão meramente elucidativa, no sentido de ressaltar que a influência do direito italiano, embora presente, não se faz de forma integral, o que exige cautela na leitura e interpretação das normas e textos.
} 
ao menos que haja correlação teórica entre as determinações legais, sobretudo no que tange ao conceito do agente econômico em tela.

Assim, especificamente, pretende-se verificar se o microempreendedor individual pode efetivamente ser reconhecido como o empresário conceituado pelo Código Civil, uma vez que este conceito é utilizado pela Lei Complementar $n^{\circ} 123 / 06$, em seu artigo 18-A, $\S 1^{\circ}$.

$\mathrm{Na}$ investigação das hipóteses a serem apresentadas, parte-se dos seguintes problemas: $\mathrm{O}$ microempreendedor individual pode ser reconhecido como empresário a que se refere o artigo 966 do Código Civil ou lhe faltaria o atributo da organização no desenvolvimento da atividade econômica? Considerando as idiossincrasias derivadas das características próprias do microempreendedor individual, pode-se verificar neste agente econômico a concentração dos perfis da empresa definidos por Alberto Asquini? No caso de distanciamento entre o conceito de empresário do Artigo 966 do Código Civil e o conceito de MEI da LC 123/06, será possível dizer que a Teoria da Empresa pode ter interpretação diversa daquela proposta como sendo o Perfil Corporativo de Alberto Asquini?

Dois fatores contribuem para os questionamentos acima: 1) o quantitativo que a legislação autoriza ao microempreendedor individual auferir; 2) a permissão para contratação de colaborador da empresa de forma excepcional e limitada a um único (percebendo piso salarial), nos termos do artigo 18-C da Lei Complementar $n^{\circ} 123 / 06$. Esses fatos, em especial o segundo, sugerem a mitigação do conceito de empresário determinado pelo artigo 966 do Código Civil, inobstante servir de literal referência para a definição legal do microempreendedor individual.

O estudo da temática proposta se dará por meio da análise da teoria poliédrica da empresa de Alberto Asquini (1943) e da Teoria da Firma de Ronald Coase (1937), considerando-as juntamente com os termos da legislação pátria aplicável ao microempreendedor individual, a fim de verificar se esta ostenta na prática a fundamentação teórica que autoriza o enquadramento legal do microempreendedor individual como empresário propriamente dito.

As hipóteses estabelecidas possuem fundamentos teóricos que as legitimam, como se verificará a partir da leitura sistemática do Fábio Ulhoa Coelho, mas também possui 
argumentos que autorizam a duvida sobre ela, consoante se verifica com a leitura do André

Luiz Santa Cruz Ramos ${ }^{3}$.

A análise dos manuais acadêmicos de direito empresarial à luz das teorias fundamentais do Alberto Asquini e do Ronald Coase permitirá uma melhor compreensão do tema e seus reflexos naturais em outros ramos do direito que são correlatos as relações falimentares, consumeristas, trabalhistas e afins.

\section{TEORIA DA EMPRESA}

A princípio, a regra legal que estabelece o Estatuto da Microempresa se apresenta como instrumento jurídico de fomento ao empreendedorismo empresarial, tendo como base principiológica a livre iniciativa enquanto liberdade empreendedorística, capacidade de explorar determinada atividade econômica, empreender de forma livre. Essa liberdade de estar no mercado é assegurada a todos independentemente de autorização do Estado, salvo os casos definidos em lei. O princípio da livre iniciativa é o fundamento da ordem econômica que permite desenvolver a produção típica do sistema capitalista.

Contudo, esta regulamentação, no que tange ao microempreendedor individual, parece se encontrar alijada de pelo menos um dos perfis da empresa estabelecidos por Alberto Asquini, que seria o corporativo; perfil este que possui similitude com a Teoria da Firma de Ronald Coase (MARTINS FILHO, 2010) e, desta forma, poder-se-ia ter um impedimento técnico em se verificar o microempreendedor individual como o empresário propriamente dito, que tem seu conceito fundamentado decorrente da Teoria da Empresa oriunda do direito italiano, de onde se extrai do artigo 2082 do Codice Civile Italiano a conceituação do empresário, enquanto agente econômico, nos termos do artigo 966 do Código Civil Brasileiro.

\footnotetext{
A Teoria da Empresa confunde às vezes, em uma única afirmação, elementos diversos. Ela é exata quando indica objetivamente um determinado sistema de organização técnicoeconômica; errônea quando, levada para o terreno subjetivo, identifica na 'emprêsa' um sujeito de direito, o que é raramente 'afirmado', sendo entretanto com frequência 'semi-afirmado'. (ASCARELLI, 1947, p. 19)
}

\footnotetext{
${ }^{3}$ Tais autores são mencionados meramente como parâmetros, mas outros estudiosos serão considerados, como Sérgio Campinho (2011), Wilges Bruscato (2011), Ronnie Preuss Duarte (2004), Sérgio de Castro Gonçalves2006), Fran Martins (2007), Gladstone Mamede (2013), Ricardo Negrão (2010), Rubens Requião (2011), Arnaldo Rizzardo (2014) e Rachel Stajn (2010), todos informados nas referências ao final do texto.
} 
foi adotada no Brasil com a pretensão de unificar os ramos do Direito Civil e Direito Empresarial, ajustando os limites entre esses Direitos, com vista a incluir na matéria atividades antes não consideradas pela Teoria dos Atos de Comércio, como prestação É importante que o estudioso do tema atente aos fatos que decorrem da conceituação teórica formulada a partir desta teoria que se propôs a unificar o direito privado italiano e que de serviços, agropecuária, empreendimentos imobiliários e atividades antes vistas como sendo de profissionais liberais e sociedades civis. "A Teoria da Empresa é, sem dúvida, um novmodelo de disciplina privada da economia, mais adequado à realidade do capitalismo superior.” (COELHO, 2015, p. 34)

\begin{abstract}
A empresa na vida moderna não tem apenas importância grande ou muito grande: tende a tornar-se exclusivista. A vida econômica é cada vez mais palco reservado das empresas. As pessoas vivem integradas em empresas. As empresas tornam-se cada vez mais os sujeitos da vida social - e até da vida política, que controlam. É evidente que uma entidade desta ordem não poderia deixar de ser de primeira importância no Direito também. (ASCENSÃO, 1998, p.137)
\end{abstract}

A partir da concepção da empresa como um "feixe de contratos" (SZTAJN, 2010, p. 93) é preciso reconhecer o empresário a partir dos elementos da empresa que ele coordena a fim de alcançar o propósito estabelecido quando do início da atividade empresarial, qual seja: o lucro.

\title{
1.1. O EMPRESÁRIO NO CÓDIGO CIVIL
}

O Código Civil, no caput do artigo 966, conceituou o empresário de forma subjetiva, entendo-se como tal aquele que exerce de forma profissional, atividade economicamente organizada de produção e circulação de bens e de serviços.

Tal conceito, derivado do artigo 2.082 do Códice Civile Italiano ${ }^{4}$, supera as dúvidas oriundas do então direito comercial, visto como uma "embalagem usada que não mais abriga o seu produto original" (DUARTE, 2004, p. 72) quando o critério para classificação do agente econômico como comerciante era objetivo e exigia a efetiva matrícula no tribunal de comércio, nos termos do artigo $4^{\circ}$ do Código Comercial de 1850.

\footnotetext{
4 “'E' imprenditore chi esercita professionalmente un'attività economica organizzata $(2555,2565)$ al fine della produzione o dello scambio di beni o di servizi $(2135,2195) . ”$
} 
A atual legislação fundamentada na Teoria da Empresa exige deste agente econômico uma atuação complexa e direcionada a determinado fim que lhe exige efetiva organização, como se verifica a partir da leitura de Rizzardo (2014, p. 43)

[...] trata-se de pessoa física que desempenha uma atividade organizada visando à obtenção de riqueza, o que se consegue com a produção de bens ou promoção de sua comercialização, bem como a prestação de serviços, de modo a conseguir resultados econômicos. O elemento caracterizador é a atividade-fím, dirigida para a prática de atos empresariais, ou para atividades próprias de empresário, que são o conjunto de atos realizados para a consecução de um fim econômico.

A organização como requisito para o reconhecimento do agente econômico como empresário é item imprescindível, tanto que a exceção contida no parágrafo único do artigo 966 do Código Civil verifica outra exceção em retorno a regra, ao afirmar que aqueles que, a princípio, não se consideram empresários por exercerem profissão intelectual, de natureza científica, literária ou artística, ainda que com o concurso de auxiliares ou colaboradores,

podem vir a ser reconhecidos como verdadeiros empresários se o exercício destas profissões constituírem elemento de empresa. Resta então necessário definir este elemento de empresa.

\subsection{ELEMENTO DE EMPRESA}

O elemento de empresa caracterizador da atividade como empresarial exige do agente econômico que a desenvolve a organização necessária ao emprego de capital e mão de obra alheia.

Uma atividade econômica organizada, isto é, uma atividade empresarial (organização do trabalho alheio e do capital próprio e alheio) que implica de parte do empresário a prestação de um trabalho autônomo de caráter organizador e a assunção do risco técnico e econômico correlato. Não é portanto empresário quem exerce atividade econômica as custas de terceiros e com o risco de terceiros. Não é tampouco, empresário, quem presta um trabalho autônomo de caráter exclusivamente pessoal, seja de caráter material, seja de caráter intelectual. Não é ainda empresário quem exerce uma simples profissão (o guia, o mediador, o carregador etc.) nem de regra, quem exerce uma profissão intelectual (o advogado, o médico, o engenheiro, etc.) a menos que o exercício da profissão intelectual 'dê lugar a uma atividade empresarial organizada sob a forma de empresa (art. 2.238), como o caso do exercício da farmácia, de um sanatório, de uma instituição de ensino etc. (ASQUINI, 1943, p.114 e 115)

A clássica posição de Alberto Asquini encontra respaldo entre autores contemporâneos como Fábio Ulhoa Coelho (2015, p. 126), Ricardo Negrão (2010, p. 70) e Sérgio Campinho (2011, p. 13). Contudo, há autores que se insurgem contrariamente a necessidade de se verificar a organização do empresário como elemento essencial a sua caracterização e reconhecimento como tal, como se verifica na leitura de André Luiz Santa Cruz Ramos (2015, p. 39), segundo o qual: "Parece-nos que essa ideia fechada de que a 
organização dos fatores de produção é absolutamente imprescindível para a caracterização do empresário vem perdendo força no atual contexto da economia capitalista."

Inobstante a tentativa de justificar a perda da força da imprescindibilidade do elemento organização para classificação do agente econômico como empresário, utilizando a atividade desenvolvida pelos microempresários e empresários virtuais como exemplos onde a ausência da organização não impediria o desenvolvimento da empresa, há que se observar que o conceito de empresário não permite promover distinções entre as categorias e espécies de empresa, ou seja, se o conceito geral derivado do artigo 966 do Código Civil utilizado pelo Estatuto da Microempresa não se permite verificar em alguns segmentos empresariais quaisquer variações do conceito.

Quiçá a atividade desenvolvida por uma das espécies legais de microempresários, como o microempreendedor individual não seja, potencialmente, uma atividade desenvolvida pelo que se depreende por empresário propriamente dito, pois dele se exige o efetivo poder de comando próprio daquele que se verifica como empreendedor. "Veremos como o conceito de atividade se coordena com o de probabilidade de ganho." (ASCARELLI, 1962, p. 146)

\footnotetext{
O poder de comando surge com a organização da atividade, não a precede nem se transfere do empresário para a atividade; ocupando o posto de nível hierárquico mais alto na cadeia de comandos da organização, investido na posição de chefe da empresa, o empresário está legitimado para exercê-lo de forma a manter a organização, a coordenação das atividades intermediárias em função do escopo produtivo. (SZTAJN, 2010, p. 137)
}

O elemento da empresa exige do empresário uma postura diferente de um mero empregador, quando se exige dele a organização do trabalho alheio está por se exigir à gestão das atividades dos colaboradores da empresa, independente da forma, tempo e valor dos contratos celebrados com estes, da mesma forma que, ao exigir o emprego de capital próprio, espera-se verificar no empresário a disposição necessária para a assunção de riscos de forma conscienciosa e, para tanto, a verificação da organização como uma atitude mais complexa, como a de um empreendedor e não como a de um mero empregador, parece ser imprescindível.

Contudo, para verificar tal hipótese, se procederá à análise da teoria poliédrica da empresa em confronto com a Teoria da Firma, a fim de verificar se as proposituras teóricas ainda se sustentam ante a regulação, especificamente no que tange ao microempreendedor enquanto objeto deste estudo.

\section{TEORIA POLIÉDRICA E TEORIA DA FIRMA}


Considerando que o direito se apropria do conceito econômico de empresa, entendese que a Teoria da Empresa deve ser considerada tanto do ponto de vista econômico quanto jurídico, o que pode indicar um certo equívoco por parte dos autores comumente adotados nos estudos iniciais do Direito Empresarial no que tange aos perfis da empresa indicados por Alberto Asquini (1943), considerando sobretudo que, a leitura mais detalhada deste autor pode permitir uma interpretação diferenciada, no sentido de que o referido autor não indicou qual dos perfis seria melhor ou preponderante sobre outros que não devem ser preteridos.

\begin{abstract}
Asquini não aceita a tal "poliedria" da empresa [...] O próprio autor, que, como já dito alhures, se limitou a narrar o fato, critica a identificação da empresa com o empresário ou com o estabelecimento. No mesmo sentido é que aludiu aos tais "perfis", defendeu um tratamento mais apurado da matéria, reconduzindo a empresa a limites mais estreitos do que os usualmente aceitos. Também para Asquini, a empresa não se confunde com empresário nem tampouco com o estabelecimento. O jurista aponta, repita-se, a incorreção do emprego do vocábulo em tais acepções. (DUARTE, 2004. p. 89)
\end{abstract}

A releitura das teorias poliédricas e da firma permitirão uma releitura do conceito de empresário a partir do artigo 966 do Código Civil que talvez impeça o seu emprego nos termos explicitados na regulamentação do microempreendedor individual tal como pretendeu o legislador com a determinação contida na Lei Complementar $n^{\circ}$ 123/06 e suas alterações, hipótese que, se comprovada, pode sugerir uma nova revisão da legislação em tela, redefinindo este agente econômico ou reestabelecendo critérios para o seu efetivo enquadramento como empresário (microempresário ou empresário de pequeno porte).

\title{
2.1. PERFIS DA EMPRESA POR ALBERTO ASQUINI
}

A teoria poliédrica de Alberto Asquini (1943) apresenta quatro perfis da empresa, como se verifica.

O perfil subjetivo, pelo qual se verifica com certa frequência "a organização econômica da empresa pelo seu vértice, usando a palavra em sentido subjetivo como sinônimo de empresário" (ASQUINI, 1943, p. 114), atrelando a empresa, enquanto objeto de direito ao empresário, sujeito de direito propriamente dito.

Na sequência verifica-se o perfil funcional, que permite identificar a empresa como a "atividade profissional organizada do empresário" (ASQUINI, 1943, p. 116), como uma espécie de força em movimento, com foco em determinado e com escopo produtivo.

No que tange ao perfil objetivo ou patrimonial, o autor reconhece a empresa como mero conjunto de bens, ou seja, objeto de direito, onde "o fenômeno econômico da empresa 
projetado sobre o terreno patrimonial, dá lugar a um patrimônio especial distinto, por seu escopo, do restante patrimônio do empresário" (ASQUINI, 1943, p. 118) aproximando-a do conceito de estabelecimento empresarial.

Por fim, tem-se o perfil corporativo ou organizacional, o qual atribui à empresa o aspecto de instituição, como "um núcleo social organizado em função de um fim econômico comum" (ASQUINI, 1943, p. 122) no qual estariam reunidos o empresário, os colaboradores da empresa e terceiros interessados, todos conectados por contratos, sendo estes o ponto central de onde decorrem todas as ações do empresário correlatas à empresa.

Como se vê, os perfis da empresa definidos não se ignoram ou se superam, não sendo, portanto, o caso de preterir um em detrimento do outro, mas de interpretá-los para melhor conceber a empresa, enquanto objeto de direito, de titularidade do sujeito de direito empresário.

Os três primeiros perfis fazem menção a realidades de suma importância na Teoria da Empresa, a empresa, o empresário e o estabelecimento empresarial, conectados pelo quarto perfil que se reporta ao dinamismo organizacional essencial à atividade empresarial, não havendo razão para não se reconhecer, tal como se fazia à época de Alberto Asquini, quando tais conceitos eram intimamente ligados, "de tal sorte que, inclusive, o próprio Asquini equiparou os conceitos" (MARTINS FILHO, 2010, p. 382).

A partir destes perfis, verifica-se que a Teoria da Firma de Ronald Coase (1937) permite reconhecer na organização da atividade a ser desenvolvida pelo empresário o elemento da empresa essencial à busca de um resultado eficiente por parte deste agente econômico.

\subsection{A FIRMA POR RONALD COASE}

O contexto da Teoria da Firma de Ronald Coase (1937) permite a visualização desta como empresa, "um conjunto de contratos coordenados que levam à execução da função produtiva" (MARTINS FILHO, 2010, p. 383).

Sendo a empresa a atividade que agrega capital e trabalho a fim de produzir bens e/ou serviços para o mercado, o empresário deve ser visto como o coordenador dos contratos que se fazem necessários à produção, considerando que, "uma importante função dos contratos é fazer recair sobre uma das partes o risco das variações de preço" (POSNER, 2010, p. 217). 
Assim, ao se reconhecer a necessidade de assunção dos riscos pelo empresário, podese verificar que os contratos por ele celebrados, num contexto do mercado, não tem a função de apenas regular os preços dos produtos e/ou serviços disponibilizados, mas, também de balizar os custos de produção.

Ademais, não cabe ao interprete afirmar o que a norma não explicita. Uma vez que o legislador não determina critérios que distinguem empresários em níveis diferentes de empreendimento, sendo o conceito legal aplicável a todos os mencionados no Estatuto da Microempresa, não há que se falar que o microempreendedor individual estaria isento de desenvolver seu mister de forma organizada. Do contrário estar-se-ia alijando-o das possibilidades de variações de sua empresa.

Other things being equal, therefore, a firm will tend to be larger:

a) the less the costs of organising and the slower these costs rise with an increase in the transactioons organised.

b) the less likely the entrepreneur is to make mistake and the smaller the incrase in mastakes with an incrase in the transactions organised.

c) the greater the lowering (or the less the rise) in the supply price of the factors of production to firm of larger size. ${ }^{5}$ (COASE, 1937, p. 397)

A Teoria da Firma de Ronald Coase (1937) permitiu reconhecer que o mercado funciona em vista da formação de preços, custos de produção e custos de transação, sendo estes últimos atinentes à aquisição de informações, concretizações de metas e contratos (MARTINS FILHO, 2010, p. 383) e, uma vez que o microempreendedor individual atua no mercado, tais circunstancias se aplicam a este, de forma que, ou este agente econômico detém e exerce organização ou ele não pode ser visto como empresário propriamente dito.

\footnotetext{
${ }^{5}$ Em igualdade de circunstâncias, portanto, uma empresa tenderá a ser maior:

a) menos os custos de organização e mais lento estes custos aumentam com um aumento nas transações organizadas.

b) a menos provável que o empreendedor é fazer com que o erro e menor o aumento de erros com um incrase nas operações organizados
} 


\section{MICROEMPREENDEDOR INDIVIDUAL}

O microempreendedor individual é identificado como uma variação da microempresa, assim definida pela Lei Complementar $n^{\circ} 123 / 06$, alterada pela Lei Complementar $n^{\circ}$ 128/08, conhecida como Estatuto da Microempresa.

A regulação especial destinada a estes agentes econômicos decorre da tutela constitucional destinada ao fomento à livre iniciativa, à valorização do trabalho humano como alternativa à redução das desigualdades sociais e, especialmente, à defesa aos empreendimentos de pequena monta, como se depreende dos artigos 170, IX e 179 da Constituição Federal de 1988.

\subsection{CARACTERÍSTICAS LEGAIS INSTRUMENTAIS}

Com a edição da citada lei complementar foi criada esta nova espécie do gênero microempresa dito empresarial que se somou ao microempresário e ao empresário de pequeno porte no rol dos agentes econômicos que possuem regulação diferenciada para o exercício da empresa.

\subsubsection{RECEITA BRUTA ANUAL}

Apesar de o microempreendedor individual ser uma inovação, instituído pela Lei Complementar $n^{\circ} 128 / 08$, os dois outros protegidos por lei em razão do princípio da isonomia já encontram regulação diferenciada desde a Lei $n^{\circ} 7.256 / 84$, substituída pela Lei $n^{\circ}$ 8.864/94, sucedida pela Lei ${ }^{\circ}$ 9.317/96 e posteriormente pela Lei $n^{\circ}$ 9.841/99 que precedeu a atual Lei Complementar $n^{\circ} 123 / 06$, alterada pela Lei Complementar $n^{\circ} 128 / 08$.

Assim, enquanto o microempresário é reconhecido naquele que aufere em cada anocalendário a receita bruta igual ou inferior a $\mathrm{R} \$ 360.000,00$ (trezentos e sessenta mil reais) e o empresário de pequeno porte como aquele que aufere no mesmo período uma receita bruta

c) maior será a redução (ou menos o aumento) no preço de fornecimento dos factores de produção para a empresa de maior porte. (Tradução livre) 
superior a $\mathrm{R} \$ 360.000,00$ (trezentos e sessenta mil reais) e igual ou inferior a $\mathrm{R} \$ 3.600 .000,00$ (três milhões e seiscentos mil reais), o microempreendedor individual está limitado a perceber receita bruta anula no limite de $\mathrm{R} \$ 60.000,00$ (sessenta mil reais).

\footnotetext{
Portanto, embora se tenha uma microempresa, trata-se de um tipo especial, restrito: a todo pequeno empresário corresponde uma microempresa, mas, mutatis mutandis, nem toda microempresa corresponde um pequeno empresário; pode corresponder a um empresário individual que tenha receita bruta anual superior a sessenta mil reais ou a uma sociedade simples ou empresária, independente de sua receita bruta anual. Nenhuma sociedade, ainda que a sua receita bruta anual seja muito inferior a sessenta mil reais, caracteriza-se como pequeno empresário; a expressão do artigo 970 do Código Civil, nos termos do citado artigo 68 do Estatuto Nacional da Microempresa e da Empresa de Pequeno Porte, interpreta-se restritivamente, aludindo a uma pessoa natural (pessoa física). (MAMEDE, 2013, p. 105)
}

Ou seja, todo microempreendedor individual é considerado microempresário, mas nem todo microempresário será microempreendedor individual. Desta forma, não se pode deixar de transparecer a diferença entre o microempreendedor individual e o pequeno empresário, ambos espécies do gênero da microempresa, mas gozadores de diferentes favores legais, sendo o primeiro maior beneficiário do regime tributário ultra simplificado e de baixo custo, o segundo, em que pese a possibilidade de enquadramento no regime do Simples, este não é tão benéfico quanto ao destinado ao microempreendedor individual, embora possa se valer das benesses registrais do 970 e 1179.

Não só por conta da questão financeira da limitação ao rendimento anual a um valor determinado, mas por conta das limitações de ordem prática relativas a sua atuação em si.

\subsubsection{ORGANIZAÇÃO DE MÃO DE OBRA ALHEIA}

O artigo 18-C da Lei Complementar no 123/06, referindo-se o artigo 18-A do mesmo diploma legal, limita a atuação do empresário que pretende se estabelecer como microempreendedor individual exigindo que este possua, no máximo, um único colaborador da empresa contratado como empregado e que este receba exclusivamente um salário mínimo ou o piso salarial da categoria profissional.

Se ao empresário é exigida a organização do capital e da mão de obra alheia, a referida determinação legal acaba por mitigar a percepção do microempreendedor individual como empresário a que se refere o artigo 966 do Código Civil.

\subsubsection{OBRIGAÇÃO REGISTRAL}


Inobstante o registro empresarial ter natureza jurídica declaratória da empresariedade, vez que constitutivo da personalidade das pessoas jurídicas de direito privado (artigos 45 e 985 do Código Civil) e declaratório da existência da relação societária nos termos do artigo 986 do Código Civil, e, não haver óbice em se reconhecer como empresário de fato aquele que desenvolve a atividade nos termos do artigo 966 do Código Civil mas ainda não procedeu ao competente ato de registro, há que se verificar que a distinção da forma de registro do microempreendedor individual em relação aos que não se enquadram neste conceito fortalece o argumento que se apresenta para o não reconhecimento daquele agente econômico como empresário propriamente dito.

Uma vez que o registro do microempreendedor individual dispensa sua presença e apresentação de documentos no Registro Publico de Empresas Mercantis a cargo das Juntas Comerciais, nos termos da Lei $n^{\circ}$ 8.934/94, consoante determina o artigo 967 do Código Civil, sendo-lhe licito registrar-se através do portal do empreendedor, sitio virtual vinculado ao Governo Federal, verifica-se que uma das condições formais para o reconhecimento do microempreendedor individual como empresário foi eliminado, colocando em questão o reconhecimento deste como empresário.

Inobstante a disciplina privatista do ato jurídico poder permanecer independente da disciplina publicista da atividade em si (ASCARELLI, 1962, p. 147), as isenções, limitações e exceções reguladas pela Lei Complementar no 128/08 em atenção ao microempreendedor individual, a despeito de serem justificadas por alguns autores contemporâneos (MAMEDE, 2013) por meio dos princípios constitucionais protetivos e de fomento à atividade econômica empresarial, podem, quiçá ter se excedido na regulação da exceção, alijando-o por completo da regra destinada ao empresário, de forma a ter proporcionado a criação de um tipo hibrido ou sui generis de agente econômico, distinto por completo do empresário tal como se conhece. $\mathrm{Ou}$, ainda, ter simplesmente estabelecido a formalização do autônomo que, diante da atividade exercida, não possuía órgão próprio para registro e regularização, como já dispunham os exercentes de profissão regulamentada em relação aos seus órgãos de classe.

\subsection{AUSÊNCIA DO PERFIL CORPORATIVO NO MICROEMPREENDEDOR INDIVIDUAL}

Da mesma forma que "da proibição de uma atividade não pode derivar a sua nulidade; não deriva nem mesmo, necessariamente, a nulidade dos atos isolados, que podem 
permanecer válidos embora sendo ilícita a atividade" (ASCARELLI, 1962, p. 148), aquele que se registra, mesmo que por via transversa, como empresário, sem o ser, deve suportar os ônus decorrentes de sua atividade.

Os termos constantes na Lei Complementar $\mathrm{n}^{\circ} \quad 128 / 08$ distanciam o microempreendedor individual do perfil corporativo da empresa, uma vez que limita sua capacidade organizativa, desconsiderando que "o jurista não pode, em cada caso concreto, identificar aquele que economicamente, é empresário" (ASCARELLI, 1962, p. 149).

Sendo o empresário considerado como um "coordenador dos fatores de produção" (ASCARELLI, 1962, p. 149), a partir do momento que o legislador impede o microempreendedor individual de organizar plenamente os elementos da empresa, prevendo inclusive sanção de multa, caso venha obter êxito no empreendimento de forma a perceber uma receita superior ao teto previsto em lei, está procedendo contrariamente a determinação constitucional de fomentar à livre iniciativa por meio de aplicação equivocada da isonomia.

Com a capacidade de organização da atividade econômica exercida profissionalmente pelo microempreendedor individual mitigada por lei, a determinação do artigo 18-A da Lei Complementar $n^{\circ}$ 123/06 fica prejudicada na prática, sendo impossível reconhecê-lo como o empresário definido no artigo 966 do Código Civil.

\section{CONCLUSÃO}

Considerando a problemática proposta, partiu-se da hipótese de que o perfil corporativo descrito por Alberto Asquini, considerado juntamente com os demais perfis, permite verificar juridicamente a empresa consoante definida pela Teoria da Firma de Ronald Coase, mas tais conceitos foram ignorados pela texto legal destinado ao microempreendedor individual que se encontra, na prática, distante do conceito de empresário, uma vez que dele não se exige de forma obrigatória, mas sim limitada e excepcional, a gestão de mão de obra, como se o controle de colaboradores da empresa não fosse essencial no exercício da atividade empresarial.

Tal fato, somado à limitação legal de sua receita bruta anual e a não obrigatoriedade de submissão dos atos de registro ao Registro Público de Empresas Mercantis à cargo das Juntas Comerciais, não permite que se aceite este agente econômico como empresário de fato ou de direito.Há duvidas ainda se sua qualificação como microempreendedor é razoável, posto que, de um empreendedor exige-se o desenvolvimento de uma atividade econômica de forma profissional e efetivamente organizada. 
Por fim, pensa-se se a persecução da aceitação do microempreendedor individual como se empresário fosse não estaria por servir como justificativa para eventual deturpação na contratação de trabalhadores como autônomos, quando na verdade deveriam ser empregados nos termos definidos pela Consolidação das Leis Trabalhistas. Mas esta hipótese deverá ser verificada em estudo diverso a ser definido a partir de outro objeto e nova problemática.

\section{REFERÊNCIAS}

ASCENSÃO, José de Oliveira. Direito comercial. Vol. 1, Lisboa, Faculdade de Direito de Lisboa, 1998.

ASQUINI, Alberto. Perfis da empresa. Revista de Direito Mercantil, Industrial, Econômico e Financeiro, São Paulo, v. 35, n. 104, out/dez/96. São Paulo: RT, 1996.

ASACARELLI, Túlio. L'Impreditore. In Curso di Diritto Commerciale. Introduzione e Teoria dell'Impresa. Trad. Fábio Konder Comparato. $3^{\text {a }}$ ed. Milano Giuffre, 1962, p. $145 / 160$.

BRASIL, Lei $\mathbf{n}^{\mathbf{0}} \mathbf{5 5 6}$, de 25 de junho de 1850. Disponível em <http://www.planalto.gov.br/ccivil_03/Leis/L0556-1850.htm>, acesso em 28 de fevereiro de 2016.

, Decreto-lei $\mathbf{n}^{\mathbf{0}} \mathbf{4 . 6 5 7}$, de 4 de setembro de 1942. Disponível em <http://www.planalto.gov.br/ccivil_03/Decreto-Lei/Del4657.htm>

Lei $\mathbf{n}^{\mathbf{0}}$ 7.256, de 27 de novembro de 1984. Disponível em <http://www.planalto.gov.br/ccivil_03/LEIS/L7256.htm>

, Constituição da República Federativa do Brasil, de 05 de outubro de 1988. Disponível em <http://www.planalto.gov.br/ccivil_03/Constituicao/Constituicao.htm>, acesso em 28 de fevereiro de 2016.

—, Lei $\mathbf{n}^{\mathbf{0}} \mathbf{8 . 8 6 4}$, de 28 de março de 1994. Disponível em <https://www.planalto.gov.br/ccivil_03/Leis/L8864.htm>, acesso em 28 de fevereiro de 2016.

—, Lei $\mathbf{n}^{\mathbf{0}} \mathbf{9 . 3 1 7}$, de 5 de dezembro de 1996. Disponível em 
〈http://www.planalto.gov.br/ccivil_03/Leis/L9317.htm>, acesso em 28 de fevereiro de 2016.

, Lei $\mathbf{n}^{\mathbf{0}}$ 9.841, de 5 de outubro de 1999. Disponível em <http://www.planalto.gov.br/ccivil_03/LEIS/L9841.htm>, acesso em 28 de fevereiro de 2016. , Lei no 10.406, de 10 de janeiro de 2002. Disponível em < http://www.planalto.gov.br/ccivil_03/LEIS/2002/L10406.htm>, acesso em 28 de fevereiro de 2016.

Lei Complementar $\mathbf{n}^{\mathbf{0}}$ 123, de 14 de dezembro de 2006. Disponível em <http://www.planalto.gov.br/ccivil_03/Leis/LCP/Lcp123.htm>, acesso em 28 de fevereiro de 2016.

, Lei Complementar $\mathbf{n}^{\mathbf{0}} \mathbf{1 2 8}$, de 19 de dezembro de 2008. Disponível em $<$ https://www.planalto.gov.br/ccivil_03/leis/lcp/Lcp128.htm> , acesso em 28 de fevereiro de 2016.

_ Lei $\mathbf{n}^{\mathbf{0}}$ 12.441, de 11 de julho de 2011. Disponível em < http://www.planalto.gov.br/ccivil_03/_Ato2011-2014/2011/Lei/L12441.htm> , acesso em 28 de fevereiro de 2016.

DEPARTAMENTO DE REGISTRO EMPRESARIAL E INTEGRAÇÃO- DREI.

Manual de Registro de Empresário Individual. Disponível em

<http://drei.smpe.gov.br/legislacao/instrucoes-normativas/titulo-menu/pasta-instrucoesnormativas-em-vigor-04/in-10-2013-anexo-1-manual-de-registro-de-empresario-individual08-09-2014.pdf>, acesso em 28 de fevereiro de 2016.

, DEPARTAMENTO DE REGISTRO EMPRESARIAL E INTEGRAÇÃO - DREI. Relatório estatístico mensal - nacional período: 01/08/2015 a 31/08/2015. Disponível em $<$ http://drei.smpe.gov.br/assuntos/estatisticas/pasta-mensal-nacional-2015/relatorioestatistico-mensal-agosto-2015.pdf>, acesso em 28 de fevereiro de 2016.

, CÂMARA DOS DEPUTADOS. PL 1572/2011, institui o Código Comercial. Disponível em 〈http://www.camara.gov.br/proposicoesWeb/fichadetramitacao?idProposicao=508884>, acesso em 28 de fevereiro de 2016. 
BESSA, Fabiane Lopes Bueno Netto. Responsabilidade social das empresas. Práticas sociais e regulação jurídica. Lumen Juris, Rio de Janeiro, 2006.

BRUSCATO, Wilges. Manual de direito empresarial brasileiro. São Paulo, Saraiva, 2011

CAMPINHO, Sérgio. $\mathbf{O}$ direito de empresa à luz do código civil. $12^{\mathrm{a}}$ ed. revista e atualizada de acordo com as Leis ${ }^{\circ}$ 12.441/2011, 12.399/2011 e 12.375/2010, Rio de Janeiro, Renovar, 2011.

COELHO, Fábio Ulhoa. Curso de direito comercial. Direito de empresa. 19a edição, vol. 1, São Paulo, Saraiva, 2015.

COMPARATO, Fábio Konder. Direito empresarial: estudos e pareceres. São Paulo, Saraiva, 1995. p. 3-37.

DUARTE, Ronnie Preuss. Teoria da Empresa à luz do novo Código Civil Brasileiro. São Paulo, Método, 2004.

FERES, Marcos Vinício Chein. Regulação, intervenção do Estado na economia e políticas públicas: Uma leitura crítica a partir do direito como identidade. In BANNWART

JÚNIOR, Clodomiro José; FERES, Marcos Vinício Chein e KEMPFER, Marlene (Organizadores). Direito e inovação. Estudos críticos sobre Estado, empresa e sociedade. Juiz de Fora: Editora UFJF, 2013.

GAMBOGI, Luís Carlos Balbino. Democracia e desenvolvimento. In FIUZA, César e NEVES, Rúbia Carneiro. (Coord.) Iniciativa privada e negócios. Belo Horizonte, Del Rey, 2012.

GONÇALVES, Sérgio de Castro. Patrimônio, família e empresa: Um estudo sobre a transformação no mundo da economia empresarial. São Paulo, Negócio Editora, 2000.

LEITE JÚNIOR, Carlos Antônio Goulart. Affectio societatis: Na sociedade civil e na sociedade simples. Rio de Janeiro, Forense, 2006.

MAMEDE, Gladston. Direito empresarial brasileiro: empresa e atuação empresarial. vol. 
1, $7^{\mathrm{a}}$ ed. São Paulo, Atlas, 2013.

MARTINS FILHO, Giovani Magalhães. O provável confronto entre alberto asquini e ronald coase: uma análise dos perfis de empresa a partir da Teoria da Firma. Trabalho publicado nos Anais do XIX Encontro Nacional do CONPEDI realizado em Fortaleza - CE nos dias 09, 10, 11 e 12 de Junho de 2010. Disponível em: <http://www.publicadireito.com.br/sistemasaux/listaaprovados.htm>, acesso em 28 de fevereiro de 2016.

MARTINS, Fran. Curso de direito comercial: empresa comercial, empresários individuais, microempresários, sociedades comerciais, fundo de comércio. $31^{\mathrm{a}}$ edição, revista e atualizada, Rio de Janeiro, Forense, 2007.

MAMEDE, Gladstone. Direito empresarial brasileiro. Empresa e atuação empresarial. vol. 1, $7^{\text {a }}$ edição, São Paulo, Atlas, 2013.

NEGRÃO, Ricardo. Manual de direito comercial e de empresa. vol. 1, $7^{\mathrm{a}}$ ed. São Paulo, Saraiva, 2010.

NEVES, Rúbia Carneiro. Limites da autonomia privada e a regulação dos negócios. In FIUZA, César e NEVES, Rúbia Carneiro. (Coord.) Iniciativa privada e negócios. Belo Horizonte, Del Rey, 2012.

PINHEIRO, Armando Castelar.; SADDI, Jairo. Direito, Economia e Mercados. Rio de Janeiro, Elsevier, 2005.

POSNER, Richard A. A Economia da justiça. Trad. Evandro Ferreira e Silva. Rev. Aníbal Mari. São Paulo: Martins Fontes, 2010.

_ _ Para além do Direito. Trad. Evandro Ferreira e Silva. Marins Fontes: São Paulo, 2009.

RAMOS, André Luiz Santa Cruz. Direito empresarial esquematizado. $5^{\text {a }}$ ed. revi. atual. e ampl. Rio de Janeiro, Forense, 2015.

REQUIÃO, Rubens. Curso de direito comercial. $30^{\mathrm{a}}$ edição revista e atualizada por Rubens 
Edmundo Requião, $1^{\text { }}$ vol., São Paulo, Saraiva, 2011.

RIZZARDO, Arnaldo. Direito de empresa. $5^{\text {a }}$ edição, revista, atualizada e ampliada, Rio de Janeiro, Forense, 2014.

STAJN, Rachel. Teoria jurídica da empresa: atividade empresária e mercados. $2^{\mathrm{a}}$ edição, São Paulo, Atlas, 2010. 